\title{
Mengapa Indonesia Memerlukan Ilmu Sejarah? Beberapa Gagasan untuk 'Hilirisasi' Historiografi
}

\author{
Bambang Purwanto \\ Departemen Sejarah, Fakultas Ilmu Budaya, Universitas Gadjah Mada \\ Pos-el: bambang.fib@ugm.ac.id
}

\begin{abstract}
History is always considered unable to make a real contribution when dealing with everyday life that demands things that are pragmatic from the practicalities of a science. Through "hilirisasi" historiography combined with the principles of commodification in the frame of "consuming history", this paper shows that history when understood as historiography is a science that is able to equip both individuals and groups to meet the needs of daily life, as a representation the intelligence and productivity of the nation within the grand framework of entrepreneurship and innovation. History is an inspiration for "dreamers" to take creative, innovative, and productive actions in the Industrial 4.0 and 5.0 eras. As a result, each people who learn history are able to create entrepreneurial opportunities both for themselves and the wider community in order to realize the prosperity of the nation.
\end{abstract}

Keywords: Historiography; history; hilirisasi; commodification; productivity; entrepreneurship

\begin{abstract}
Abstrak
Selama ini, sejarah selalu dianggap tidak mampu memberi sumbangan yang nyata ketika berhadapan dengan kehidupan sehari-hari, yang menuntut hal-hal yang bersifat pragmatis dari praktis sebuah ilmu. Melalui "hilirisasi" historiografi yang dipadu dengan prinsip-prinsip komodifikasi dalam bingkai "mengonsumsi sejarah", tulisan ini menunjukkan bahwa sejarah ketika dipahami sebagai historiografi merupakan sebuah ilmu yang mampu membekali, baik individu maupun kelompok, untuk berproduksi memenuhi kebutuhan kehidupan sehariharinya, sebagai sebuah representasi kecerdasan dan produktivitas bangsa dalam kerangka besar kewirausahaan dan inovasi. Sejarah adalah inspirasi untuk para "pemimpi" melakukan tindakan-tindakan kreatif, inovatif, dan produktif pada era Industri 4.0 dan 5.0. Hasilnya, setiap anak bangsa yang belajar sejarah mampu menciptakan peluang kewirausahaan, baik untuk dirinya sendiri maupun masyarakat yang luas, dalam rangka mewujudkan kesejahteraan dan kemakmuran bangsa.
\end{abstract}

Kata kunci: Historiografi; sejarah; hilirisasi; komodifikasi; produktivitas; kewirausahaan

\section{Pendahuluan}

Setiap kali berbicara tentang penelitian sejarah dan pendidikan sejarah, maka nilai yang bersifat normatif selalu menjadi unsur utama yang dicari relevansinya bagi kehidupan kekinian, khususnya nasionalisme yang sarat dengan kepentingan ideologis. Akibatnya, sejarah selalu dianggap tidak mampu memberi sumbangan yang nyata karena hasil dari kajian sejarah dan proses pembelajaran sejarah tidak nyata dan tidak aplikatif ketika 
berhadapan dengan kehidupan sehari-hari, yang menuntut hal-hal yang bersifat pragmatis dari praktis sebuah ilmu. Apalagi pada era (Revolusi) Industri 4.0 dan 5.0, yang ditandai oleh dominasi cyber-physical systems seiring dengan berkembangnya teknologi digital ini (Buhr, 2017; Morrar et al., 2017), smart factory mampu menyalin secara virtual fisik dunia dan membuat keputusan terdesentralisasi yang didukung oleh keunggulan teknologi informasi, yakni ketika ruang dan waktu sebagai sebuah kenyataan menjadi kabur, ketika masa lalu, masa kini, dan masa depan berdiri sejajar tanpa batas dalam ruang virtual.

Tulisan ini mendekonstruksi keraguan terhadap penelitian dan pendidikan sejarah yang ada selama ini dengan melihat historiografi sebagai bagian yang tidak terpisahkan dari situasi kekinian. Belajar dari sejarah, tidak ada yang perlu dibesar-besarkan dari era (Revolusi) Industri 4.0 dan 5.0 saat ini karena perubahan telah terjadi sejak dahulu. Manusia pada prinsipnya selalu berusaha untuk menyesuaikan diri dengan setiap perubahan yang terjadi walaupun dalam kenyataannya ada yang berhasil dan ada juga yang gagal.

Dalam upaya agar tidak terjadi kegagalan, tulisan ini akan difokuskan pada pertanyaan utama: "Mengapa dan bagaimana penelitian sejarah serta pendidikan sejarah dapat berfungsi sebagai inspirasi bagi tindakan dan sikap kreatif, inovatif, serta produktif di tengah perubahan cepat yang terjadi saat ini?" Tulisan ini bertujuan untuk menunjukkan bahwa sejarah ketika dipahami sebagai historiografi merupakan sebuah ilmu yang mampu membekali, baik individu maupun kelompok, untuk berproduksi memenuhi kebutuhan kehidupan sehari-harinya sebagai sebuah representasi kecerdasan dan produktivitas bangsa dalam kerangka besar kewirausahaan dan inovasi, tidak semata-mata fungsi ekonomis yang kapitalistik.

\section{Ilmu yang Selalu dipinggirkan}

Dari waktu ke waktu, kita selalu mendengar para elite politik, birokrat, dan bahkan ilmuan di Indonesia berbicara tentang sejarah sebagai sesuatu yang maha penting. Pernyataan Presiden Soekarno tentang arti penting sejarah terus dikutip, terutama ketika sedang memperingati peristiwa-peristiwa penting dalam sejarah Indonesia. Akan tetapi, pada saat yang sama, pendapat profesional para sejarawan, seperti juga para ilmuan humaniora lainnya, tidak pernah mau didengar. Keikutsertaan sejarawan dalam menentukan kepentingan bangsa, seperti membangun kerangka berpikir dalam penyusunan kebijakan atau strategi keunggulan bangsa, sangat terbatas, kalau tidak mau disebut tidak ada sama sekali sebagai sebuah sistem. Padahal, para sejarawan merupakan representasi dari ilmu sejarah yang menjadi salah satu syarat harus bagi adanya sebuah konstruksi sejarah yang dianggap penting itu.

Sementara itu, ada kesan yang kuat bahwa sejarawan Indonesia juga tidak berdaulat atas sejarah bangsanya sendiri. Para sejarawan asing yang menulis sejarah Indonesia dianggap lebih unggul dalam segala hal ketika menulis sejarah Indonesia (Purwanto, 2006). Selain itu, keberadaan sejarah di ruang publik saat ini, yang merepresentasi naratif bangsa, hampir sebagian besar juga bukan merupakan hasil kerja profesional sejarawan, melainkan kerja media, sistem informasi, dan seni. Semua itu selaras dengan kenyataan bahwa regenerasi sejarawan Indonesia juga tidak pernah dianggap penting. Keberadaan 
mereka lebih merupakan inisiatif pribadi, bukan bagian dari desain besar pengembangan sumber daya bangsa sebagai sebuah keutuhan yang dibutuhkan. Para calon sejarawan harus berjuang sendiri ketika negara hampir dapat dikatakan tidak pernah hadir dalam memproduksi para sejarawan dari satu generasi ke generasi berikutnya. Negara baru hadir ketika para sejarawan datang dengan naratif historiografi yang tidak diharapkan oleh sebuah rezim atau oleh mereka yang sedang berkuasa. Para sejarawan dengan mudah dituduh telah mengkhianati bangsa karena naratif historiografi yang dihasilkan berdasarkan bukti-bukti dan interpretasi mutakhir berbeda dengan yang selama ini telah menjadi kesadaran kolektif bangsa. Para sejarawan dengan mudah menjadi pesakitan karena kerja keilmuannya.

Tidak adanya sejarah secara khusus dan humaniora secara umum merupakan kesan pertama yang muncul ketika membaca berita-berita dan dokumen tentang "hilirisasi" penelitian nasional perguruan tinggi, baik yang ada di dokumen dan laman-laman resmi maupun di media massa populer. Sebagian besar berita dan dokumen hanya memuat tiga kata kunci, yaitu industri, teknologi, dan ekonomi ketika berbicara tentang "hilirisasi" penelitian. Sangat sulit untuk menemukan kata kebudayaan, nilai, etika, atau demokrasi yang dihubungkan dengan "hilirisasi" penelitian. Melalui pendekatan instrumentalisnya, rezim teknokratis mulai dari tingkat pusat sampai dengan di perguruan tinggi masingmasing mendasarkan kerangka berpikir dan menerjemahkan "hilirisasi" penelitian dengan keuntungan siap saji, terutama yang bersifat ekonomis dengan mengatasnamakan kepentingan dan kesejahteraan bangsa.

Slogan mengatasnamakan bangsa ini perlu penekanan lebih lanjut karena hal seperti ini sangat mudah terjebak pada klaim sepihak, sempit, dan parsial tanpa ada keinginan untuk melihat kenyataan yang dihadapi bangsa secara holistik sebagai sebuah keutuhan dalam menentukan prioritas penelitian. Mengikuti cara berpikir dalam "Sajak Atas Nama" karya Mustofa Bisri maka yang ada adalah atas nama kepentingan dan kesejahteraan bangsa untuk memperkaya pemilik modal dan melegitimasi kedudukan dan kekuasaan.

Hampir seluruh pemahaman tentang makna hilirisasi" beranjak dari pendapat bahwa "hasil riset atau penelitian ... harus sampai menjadi produk yang bisa dikomersialkan untuk kesejahteraan masyarakat" sebagaimana dikatakan oleh Menteri Riset, Teknologi, dan Pendidikan Tinggi pada September 2015 (USID, 2016). Dalam bahasa yang lain, "hilirisasi" penelitian selalu dimaknai sebagai "inventor, innovator, and investor collaboration" (Direktorat Jendral Kelembagaan Iptek dan Dikti, 22 Desember 2016). Oleh karena itu, tidak mengherankan jika ada perguruan tinggi yang "berencana untuk mendirikan holding company yang akan melakukan kegiatan bisnis di dalam negeri dan internasional" (Tribun Jawa Tengah, 6 Januari 2017). Padahal, secara historis, adanya hubungan simbiosis antara penelitian di perguruan tinggi dengan kesejahteraan bangsa atau bermanfaat bagi masyarakat dapat dilacak jauh ke belakang, paling tidak sejak tahun 1950-an ketika Indonesia baru memiliki beberapa perguruan tinggi.

"Hilirisasi riset" sebagai konsep dan penerapannya sama sekali bukan sesuatu yang baru dalam sejarah penyelenggaraan penelitian di perguruan tinggi di Indonesia. Hal yang baru dalam konsep "hilirisasi riset" adalah komersialisasi hasil penelitian menjadi produk industri untuk kepentingan ekonomi, karena sebelum ini semua "hilirisasi" penelitian dilakukan melalui mekanisme pengabdian kepada masyarakat. Pada saat 
itu, para perintis perguruan tinggi Indonesia bekerja mendarmabaktikan keunggulan ilmu pengetahuan, teknologi, inovasi, dan penemuan mereka sebagai sebuah kesatuan ide untuk kepentingan masyarakat, tanpa memikirkan keuntungan secara ekonomis, apalagi untuk mendapatkan posisi di lingkar dalam kekuasaan. Keberadaan usaha peningkatan mutu kesehatan masyarakat sejak Bandung Plan tahun 1951 yang kemudian berkembang menjadi Puskesmas yang dikenal saat ini (Neelakantan, 2014; Hywood \& Harahap, 2009) merupakan salah satu contoh paling klasik bagaimana "hilirisasi riset" perguruan tinggi telah bekerja dengan semangat pengabdian masyarakat, bukan komersialisasi atas industri kedokteran dan farmasi di Indonesia. Jadi, secara historis, pemahaman atas "hilirisasi riset" di perguruan tinggi yang ada pada saat ini harus dicari pada pembiayaan perguruan tinggi yang mengemuka akhir-akhir ini, bukan pada persoalan laporan penelitian yang hanya disimpan di perpustakaan, dipublikasi, atau dipatenkan (USID, 2016).

Salah satu dampak paling nyata dari cara berpikir yang bertumpu pada komersialisasi ilmu pengetahuan dan teknologi itu dapat dilihat pada naratif para teknokrat, yang berpendapat bahwa penyelenggaraan pendidikan dan penelitian untuk bidang humaniora jauh lebih murah daripada bidang sains dan teknologi. Salah satu alasan klasik yang selalu disampaikan adalah bahwa proses pembelajaran dan penelitian di dalam ilmu humaniora tidak memerlukan bahan habis pakai dan peralatan canggih yang menghabiskan anggaran yang besar. Padahal, lebih murah atau lebih mudah itu bersifat relatif dan subjektif. Silakan tanyakan kepada mereka yang mengajar keterampilan bahasa, apakah dapat menghasilkan alumni dengan kompetensi terbaik jika satu kelas dalam proses belajar mengajar diisi oleh lebih dari 25 orang mahasiswa? Karena itu, silakan dibayangkan, berapa banyak kelas, peralatan, dosen, dan jam belajar yang diperlukan untuk mendapat hasil sebaik mungkin?

Begitu juga dengan laboratorium. Selain apa yang dikenal dengan laboratorium untuk mengajar bahasa dan laboratorium untuk berlatih mengajar, sebagian besar berpikir bahwa ilmu-ilmu humaniora tidak memerlukan laboratorium sehingga tidak mengherankan, sebagai contoh, banyak doktor dan bahkan guru besar ilmu linguistik dan sastra ironisnya berpendapat bahwa ilmu mereka tidak memerlukan laboratorium. Padahal, di berbagai perguruan tinggi terkemuka, laboratorium linguistik dan laboratorium sastra merupakan salah satu kebanggaan dari kemajuan ilmu pengetahuan sebagai sebuah school of thought tersendiri.

Begitu juga dengan bidang ilmu sejarah, biarpun sedikit berbeda jika dibandingkan dengan ilmu lainnya di dalam rumpun humaniora. Jika ada program studi yang memiliki laboratorium, hampir sebagian besar masih merupakan "laboratorium-laboratoriuman" dalam rangka memenuhi syarat minimal akreditasi. Itupun sebagian besar dimiliki oleh program studi pendidikan sejarah, bukan program studi ilmu murni. Tidak adanya laboratorium yang memadai itu bukan karena para dosen berpendapat laboratorium tidak diperlukan dalam pembelajaran sejarah, melainkan karena memang tidak ada kebijakan institusional yang dapat digunakan untuk mewujudkannya. Sementara itu, ketika sebagian besar sumber sejarah Indonesia sebelum tahun 1950 tidak berbahasa Indonesia, sudah dapat diperkirakan biaya besar yang harus dikeluarkan untuk mengajarkan bahasa sumber yang sesuai dengan minat masing-masing mahasiswa.

Terlepas dari suka atau tidak suka, sebagian besar sumber sejarah Indonesia 
berbahasa Belanda dan bahkan sebagian memerlukan keterampilan khusus paleografis untuk membacanya. Keterampilan bekerja dengan sumber berbahasa Belanda ini tentu saja memerlukan biaya yang sangat besar. Akibatnya, akhir-akhir ini sangat sedikit departemen sejarah di Indonesia yang benar-benar menyelenggarakan pembelajaran bahasa Belanda secara serius sehingga para lulusan benar-benar memiliki kompetensi melakukan penelitian dengan dokumen berbahasa Belanda. Belum lagi jika dokumendokumen itu tidak tersedia di Indonesia. Sudah dapat dibayangkan berapa besar anggaran yang diperlukan untuk sebuah penelitian.

Bisa dibayangkan juga betapa besar anggaran yang diperlukan untuk mendidik seorang sejarawan yang baik, ketika seorang dosen diberi kesempatan untuk menyelenggarakan pengajaran yang mampu memenuhi standar kompetensi tertinggi bagi para alumninya. Kreativitas seorang dosen yang mengajar mata kuliah Metodologi Sejarah, misalnya, menuntut dirinya untuk membangun pemikiran kritis melalui forum diskusi intensif berkali-kali selain kuliah rutin di kelas. Dilihat dalam perspektif politik anggaran secara kuantitatif seperti juga yang digunakan untuk menghitung biaya dalam pengajaran ilmu alam, berapa banyak anggaran yang harus dikeluarkan untuk membayar narasumber dari luar yang khusus didatangkan untuk mendapat perspektif alternatif; membayar listrik yang banyak digunakan untuk menerangi dan mendinginkan ruangan, belum lagi untuk lift bagi yang memiliki gedung tinggi dengan dosen serta mahasiswa yang malas jalan kaki melewati tangga manual; dan jangan lupa biaya sebagai penghargaan atas kreativitas, hak kekayaan intelektual, dan "lembur" yang dilakukan dosen. Para teknokrat selalu berpikir bahwa semua yang dilakukan koleganya itu sudah merupakan bagian dari tupoksi seorang dosen, yang semuanya sudah diperhitungkan dalam gaji yang diterima setiap bulan. Jika pun mahasiswa harus mengeluarkan biaya lebih, itu merupakan persoalan pribadi, bukan penyelenggaraan pendidikan tinggi sebagai sebuah sistem.

Hal serupa juga akan terjadi pada praktik penelitian sejarah yang merupakan bagian yang tidak bisa dipisahkan dari kuliah Metode Sejarah dan Seminar Sejarah, yang penuh dengan kerja keterampilan penelitian. Hampir semua biaya yang dikeluarkan untuk matakuliah tersebut selama ini baru menyentuh kulit dari kompetensi yang seharusnya dimiliki. Kunjungan ke perpustakaan dan arsip hanya bersifat pengenalan, belum penelitian dalam arti yang sebenarnya. Silakan diperkirakan berapa biaya yang diperlukan untuk sebuah kerja penelitian bagi setiap mahasiswa yang harus bekerja di arsip atau perpustakaan paling sedikit selama 1/3 dari seluruh hari kuliah dalam 1 semester. Belum lagi jika mereka harus melakukannya di tempat yang bukan tempat mereka sedang belajar atau bertempat tinggal.

Hal yang sama juga berlaku jika diperlukan kerja sejarah lisan, yang memerlukan waktu yang tidak sedikit untuk akhirnya mendapatkan informasi dari para informan. Jika satu kelas ada 50 orang, berapa dosen dan asisten beserta biaya yang diperlukan untuk menyelenggarakan sebuah pembelajaran yang mampu menghasilkan tenaga kerja siap saji seperti yang dibayangkan oleh para teknokrat? Jawaban pasti akan sama, itu sudah merupakan bagian dari tupoksi, sesuatu yang tidak perlu dijadikan variabel dalam menetapkan besaran biaya pendidikan yang didapat dari dana masyarakat, APBN, hibah, dan mungkin juga pinjaman karena sejarah dianggap sebagai ilmu yang murah untuk diselenggarakan. Padahal, dalam kenyataannya, pendidikan dan pengajaran 
ilmu-ilmu humaniora dan juga dengan penelitian yang menyertainya bukan merupakan sesuatu yang murah, melainkan cara berpikir para terknokrat berorientasi politis yang membuatnya dianggap sebagai ilmu yang murahan.

Menurut Martha C. Nussbaum yang mendasari pendapatnya dari pengalaman tradisi liberal arts di Amerika Serikat, humaniora merupakan bidang yang akan sangat berpengaruh dalam mempersiapkan seseorang menjadi warga negara dan kehidupannya di dalam konteks negara itu (Nussbaum, 2016:xix). Hal ini jauh lebih mendasar daripada orientasi ekonomis, karena keuntungan ekonomis akan mengikuti ketika sebuah negara bangsa berhasil membangun masyarakat yang berorientasi pada kemajuan ilmu pengetahuan dan teknologi sebagai sebuah kebudayaan (Epstein, 2008). Mentalitas dan etos menjadi sesuatu yang penting, mengingat ilmu pengetahuan dan teknologi merupakan produk kebudayan yang menempatkan pendidikan humaniora sebagai faktor kunci. Ironisnya, sebagian teknokrat, seperti juga para politisi, lebih suka pada pendidikan yang secara singkat dapat menghasilkan keuntungan ekonomis daripada humaniora yang mampu membangun kehidupan demokrasi yang sehat untuk jangka waktu yang panjang (Nussbaum, 2016:147).

\section{Penelitian tanpa Humaniora}

Cara berpikir yang sejenis dengan penyelenggaraan pendidikan di atas juga dapat dilihat dalam konteks penelitian. Dokumen Rencana Induk Riset Nasional 2017-2045 tentu saja merupakan rujukan pokok jika sebuah penelitian ingin didanai oleh Pemerintah, yang juga berdampak terhadap rekrutmen dan pengembangan sumber daya manusia. Apakah humaniora, khususnya sejarah, diprioritaskan? Silakan lihat enam kategori pada Fokus Kelompok Makro Riset yang mencakup Riset Terapan Berbasis Sumber Daya Alam, Riset Maju Berbasis Sumber Daya Alam, Riset Terapan Manufaktur, Riset Maju Manufaktur, Riset Teknologi Tinggi, dan Riset Rintisan Terdepan, yang pada setiap kelompok dibagi dalam beberapa tema atau bidang penelitian. Oleh karena itu, ketika rencana induk itu diterjemahkan ke dalam Prioritas Riset Nasional, sosial-humaniora ditempatkan sebagai salah satu dari delapan bidang riset. Delapan bidang riset ini kemudian dikembangkan lebih lanjut menjadi beberapa bidang fokus, yaitu pangan-pertanian, kesehatan-obat, transportasi, energi-energi baru dan terbarukan, pertahanan dan keamanan, teknologi informasi dan komunikasi, material maju, kemaritiman, kebencanaan, dan akhirnya sosial humaniora-seni budaya-pendidikan, yang bukan sebagai payung keilmuan secara utuh atas tujuh bidang riset dan bidang fokus sebagaimana difungsikan bagi pada sains dan teknologi.

Di dalam bidang fokus sosial humaniora-seni budaya-pendidikan terdapat empat kajian, yaitu pembangunan sosial budaya, sustainable mobility, penguatan modal sosial, dan ekonomi sumber daya manusia. Di dalam salah satu bidang kajian, terdapat unsur seni budaya pendukung pariwisata yang secara implisit mengarah pada bidang yang akan memberi keuntungan ekonomis. Padahal, unsur yang paling penting dalam seni budaya adalah aspek imajinasi, yang di dalam humaniora merupakan salah satu faktor penting dalam membangun kemampuan berpikir. Sementara itu, di dalam dokumen disebutkan dari 8 tema "agenda riset" dengan 35 "topik riset” terdapat 4 "tema agenda prioritas" atau "tema riset prioritas" Bidang Sosial Humaniora. 
Ketika dokumen dibaca secara menyeluruh maka selain adanya persoalan serius pada logika semantik, secara struktural juga sulit menemukan benang merah sebagai sebuah rancangan besar cara berpikir yang sinkron dengan dua kata kunci, yaitu industri dan keunggulan teknologi "untuk pencapaian daya saing kompetitif perekonomian" bagi keberhasilan pembangunan (Dewan Riset Nasional, 2016:1). Menambah bukti dari pernyataan di bagian sebelumnya, tidak adanya perhatian pada konteks imajinasi di atas dapat dilihat pada pendidikan vokasional yang difokuskan untuk menghasilkan tenaga kerja yang memiliki keterampilan teknis dengan mengesampingkan keterampilan imajinatif. Oleh karena itu, tidak mengherankan bahwa hampir sebagian besar program studi pada pendidikan vokasional berkaitan dengan sains dan teknologi, sedangkan program studi bidang humaniora sangat sedikit, kecuali keterampilan berbahasa asing, pariwisata, dan kearsipan.

Sementara itu, ketika dilihat lebih jauh lagi, pada anatomi dokumen terdapat persoalan yang berkaitan dengan kesadaran kolektif, yang menunjukkan adanya peminggiran sistematis terhadap penelitian humaniora sebagai sebuah naratif. Pada awalnya tidak ada kecurigaan apa pun tentang urutan yang selalu menempatkan unsur sosial-humaniora pada bagian yang terakhir. Alasan alfabetis merupakan hal yang paling masuk akal, mengingat huruf awal " $\mathrm{"} \mathrm{memang} \mathrm{berada} \mathrm{pada} \mathrm{posisi} \mathrm{kemudian}$ jika dibandingkan dengan huruf awal "E", "H", "K", ataupun "P". Akan tetapi, tentu saja huruf awal "T" seharusnya setelah "S". Dalam kenyataan, penulisan bidang riset dilakukan tidak berdasarkan urutan alfabetis, dengan huruf awal "P" mendahului huruf awal "E", huruf "T" mendahului huruf " $H$ ", dan seterusnya. Berdasarkan hal tersebut, paling tidak ada dua kesimpulan yang bisa dibuat dari tidak teraturnya urutan alfabetis itu. Pertama, cara penulisan di dalam dokumen itu menunjukkan urutan prioritas penelitian. Kedua, hal itu dilakukan tanpa ada alasan apa pun, asal ditulis saja. Oleh karena itu, tanpa ada pikiran negatif sedikitpun, berdasarkan pengelompok yang telah dibuat dan contoh bidang serta bidang fokus yang dikemukakan di dalam dokumen itu, terdapat satu kesimpulan yang pasti. Tidak ada satupun kalimat atau bagan yang bisa dirujuk yang dapat digunakan untuk membangun sedikit harapan bahwa humaniora sebagai ilmu merupakan sesuatu yang diprioritaskan dalam penelitian yang akan dilakukan beberapa puluh tahun ke depan—ketika Proklamasi kemerdekaan bangsa Indonesia yang dilakukan oleh Soekarno dan Mohammad Hatta atas nama bangsa Indonesia genap berusia 100 tahun.

Rencana induk penelitian itu memberi pesan yang jelas bahwa industri dan keunggulan teknologi yang diperlukan oleh negara untuk "memajukan perekonomian nasional berbasis ilmu pengetahuan dan teknologi", bukan budaya dan mentalitas bangsa yang mampu membangun keunggulan bangsa sebagai sebuah sistem produksi, pengelolaan, dan distribusi sehingga "keadilan sosial bagi seluruh rakyat Indonesia" dapat dicapai sebagaimana tertulis pada sila kelima dari Pancasila. Karakter bangsa sebagai sebuah etos dianggap bukan prioritas selama keuntungan ekonomis dari "keunggulan dalam bidang iptek mampu membangun pertumbuhan ekonomi dan menghantarkan rakyatnya mencapai kesejahteraan dengan salah satu indikatornya, yaitu tingkat pendapatan yang tinggi" berdasarkan pengalaman negara maju, seperti yang tertera dalam dokumen Agenda Riset Nasional 2016-2019. Pembangunan dianggap hanya akan berhasil jika dilakukan melalui "peningkatan kemampuan ilmu pengetahuan dan 
teknologi (iptek) untuk pencapaian daya saing kompetitif ekonomi”. Padahal, menurut salah satu pendapat, faktor kunci bagi kemajuan bangsa adalah terbentuknya "budaya inovatif, inovasi budaya” (Santosa, 2017) agar dapat menghasilkan karya-karya inovatif yang memiliki nilai ekonomis .

Pernyataan di dalam dokumen yang secara eksplisit menyatakan rumusan dari agenda penelitian disusun berdasar pengalaman negara maju itu tentu saja menimbulkan keingintahuan lebih lanjut. Apakah hal itu juga didasarkan pada pengetahuan dan pemahaman sejarah tentang bagaimana dan mengapa tingkat pendapatan tinggi itu bisa dicapai sehingga menjadi indikator dari adanya pertumbuhan ekonomi dan kesejahteran rakyat yang didukung oleh keunggulan iptek di negara maju tersebut? Di dalam sejarah, revolusi ilmu pengetahuan di Eropa sejak pertengahan abad ke-16 disebabkan oleh perubahan cara berpikir dari yang bersifat teologis ke sekuler seiring dengan berkembangnya rasionalisme dan reformasi gereja; berkembangnya konsepkonsep filosofis yang didasarkan pada keingintahuan ilmiah rasional sepanjang abad ke-17 hingga awal abad ke-18 sebagai bagian dari masa pencerahan memberi ruang bagi pemikiran yang berujung pada penemuan teknologi baru; modal dan pasar yang besar tidak akan terbentuk tanpa ada ide tentang kolonialisme dan imperialisme; revolusi industri yang bermula di Inggris merupakan respons terhadap kesempatan yang mengonversi biaya tenaga kerja tinggi dengan mesin serta dukungan pasar yang luas sebagai dampak dari praktik kolonialisme dan imperialisme; akumulasi modal lebih lanjut terjadi sejak prinsip-prinsip liberalisme dan kapitalisme berkembang pesat; dan kesejahteraan rakyat atau negara sejahtera sulit dibayangkan tanpa humanisme, demokrasi, dan sosialisme yang berkembang pesat pada akhir abad ke-19.

Semua perubahan besar yang mengikutsertakan industri dan teknologi itu ternyata bersumber pada perkembangan sistem ide dan filsafat, yang membangun mentalitas serta karakter sebagai sebuah kebudayaan produktif dan menyejahterakan. Kemajuan industri, keunggulan ekonomi, dan keunggulan teknologi ternyata merupakan akibat, bukan sebab. Sebagai sebuah bangsa yang menjalani proses sejarah dan karakteristik kebudayaan yang berbeda, Indonesia tentu saja memiliki keunikannya sendiri yang tidak dapat begitu saja disamakan dengan yang lain.

Dalam sejarah Indonesia pada paruh kedua abad ke-19, sebagai contoh, penghentian kebijakan ekonomi sistem tanam paksa yang memberi keuntungan yang sangat banyak, baik kepada negara induk maupun pemerintah Hindia Belanda, harus dilihat akar penyebabnya pada perubahan filosofis yang memengaruhi tumbuhnya sistem ekonomi liberal yang menggantikan merkantilisme, yang menjalankan sistem tanam paksa. Begitu juga dengan diberlakukannya politik etis pada awal abad ke-20. Semuanya bermula dari perubahan ide tentang bagaimana mengelola sebuah koloni untuk memperbesar keuntungan yang bisa didapat sambil berandai-andai tentang negara kesejahteraan di koloni karena semakin kuatnya pengaruh sosialisme dan demokrasi di Eropa pada saat itu. Dua perubahan cara berpikir itulah yang kemudian membuka ruang bagi industrialisasi dan kemajuan teknologi di Belanda dan sekaligus keunggulan atas koloninya, biarpun seperti diketahui bersama bahwa Belanda tidak pernah benar-benar mengalami revolusi Industri (Mokyr, 1999) dengan tingkat keunggulan teknologi yang luar biasa seperti yang pernah dimiliki oleh Inggris, Jerman, dan tentu saja Amerika Serikat. Biarpun begitu, nyatanya Belanda tetap dapat menjadi "negara maju” dan "negara makmur" dengan 
bertumpu pada perdagangan dan pertaniannya. Hal serupa terjadi pada sebagian besar negara di Skandinavia. Hanya satu hal yang membuat mereka sama, yaitu kekuatan kebudayaan yang sama-sama diwariskan dari dunia Barat, yang mengalami "revolusi kebudayaan" sejak terjadinya renaisans pada abad ke-14, yang berhasil dikonversi menjadi ide atau pemikiran inovatif yang produktif sebagai sebuah kebudayaan. Penemuan baru dalam bentuk apa pun merupakan hasil dari revolusi cara berpikir, yang berbentuk teknologi dan ilmu pengetahuan serta kemudian berujung pada keuntungan ekonomis yang menyejahterakan, bukan sebaliknya.

Dalam konteks sejarah ekonomi dunia pada masa-masa kemudian, perkembangan industri dan teknologi pasca-Perang Dunia II, baik di Amerika Serikat, Eropa, maupun Jepang sampai batas tertentu, tidak terlepas dari hadirnya rezim ekonomi Keynesian yang berkembang pascadepresi ekonomi tahun 1930-an, yang membuka kesempatan ekonomi baru sehingga mendorong pertumbuhan sektor industri dan kemajuan teknologi setelah bank sentral dan pemerintah ikut campur melalui kebijakan keuangan dan kebijakan fiskal yang mengoreksi ekonomi pasar sebelumnya yang dikontrol penuh oleh pemilik modal. Kekuatan ide, atau yang kadang-kadang disebut ideologi, juga menjadi sebab berakhirnya industri manufaktur dan beralih ke industri jasa serta akhirnya ke industri informasi beserta perangkat teknologi yang menyertainya.

Setelah E.F. Schumpeter dan teman-temannya berpikir tentang lingkungan, secara perlahan-lahan tetapi pasti, industri dan teknologi beserta politik-ekonomi dan teknologinya mengarah pada segala hal yang berorientasi pada keselamatan planet bumi beserta makhluk yang ada di dalamnya. Pada awalnya dimulai dengan proyek pembangunan berkelanjutan dan akhirnya menghadirkan ekonomi hijau beserta berbagai teknologi pendukungnya yang dilabelkan sebagai ramah lingkungan serta alami. Pembangkit tenaga listrik yang bertumpu pada sumber energi fosil batu bara dan minyak bumi mulai beralih ke teknologi baru dan terbarukan, seperti tenaga angin dan surya.

Sementara itu, pemikiran tentang makanan biologis yang lebih sehat dan ramah lingkungan membuka peluang bagi munculnya berbagai teknologi, industri, dan tentu saja kesempatan ekonomi baru untuk menghindari perusakan kreatif yang disebabkan oleh kecanggihan teknologi, yang hanya bertumpu pada produksi massal dari sistem yang kapitalistik untuk memenuhi peningkatan permintaan pasar, baik karena pertambahan penduduk yang besar, perubahan gaya hidup, maupun tanggung jawab global. Sekali lagi, sejarah mengajarkan bahwa kemajuan ide atau cara berpikir yang merupakan sebuah sistem kebudayaan, yang menjadi pangkal dari industri, keunggulan teknologi, dan keuntungan ekonomis, bukan sebaliknya. Dalam bahasa yang lain, merujuk pendapat Sartono Kartodirdjo, dalam kondisi seperti ini "perlu dibentuk suatu kebudayaan teknologi yang mencakup keseluruhan pola hidup beserta etosnya sesuai dengan sistem industrial” (Kartodirdjo, 2005:172).

Apakah dasar berpikir dari "hilirisasi" penelitian dan penentuan prioritas penelitian di Indonesia yang diklaim mengacu pada pengalaman sejarah negara maju sebagaimana tertera dalam dokumen-dokumen resmi yang ada? Dilihat dari perspektif sejarah, semua yang tertuang dalam dokumen rencana induk dan agenda penelitian itu bukan sesuatu yang mengejutkan, jika "hilirisasi" penelitian perguruan tinggi di Indonesia hanya mengacu pada hubungan antara penelitian dan komersialisasi serta industri (Dewan 
Riset Nasional, 2016:5). Dengan kata lain, "hilirisasi" penelitian hanya dapat dibangun jika ada kerja sama antara dunia akademik, bisnis, dan pemerintah (Nasution, 2016) dan, tentu saja, dengan mengesampingkan masyarakat. Hal itu karena, sejak awal, penentuan prioritas penelitian didasarkan pada kerangka berpikir bahwa "dari sembilan agenda dalam Nawa Cita, yang dianggap sangat berkaitan erat dengan pengembangan iptek adalah hanya agenda ke-6 dan ke-7, yaitu meningkatkan produktivitas dan daya saing serta menggerakkan sektor ekonomi domestik" (Dewan Riset Nasional, 2016:3). Tiga kata kunci: produktivitas, daya saing, dan ekonomi domestik, ditafsirkan bukan sebagai etos, melainkan hanya pada kemampuan teknis menghadirkan teknologi yang dapat mendorong sektor industri untuk mendapat keuntungan ekonomis.

Hal itu berarti memperteguh kebinekaan dan restorasi sosial, revolusi karakter bangsa, dan menghadirkan negara tidak memerlukan penelitian karena tidak ada hubungannya dengan industri dan teknologi, apalagi jika dikaitkan dengan keuntungan ekonomi yang mampu mendongkrak pendapatan setinggi mungkin. Padahal, semua tahu berapa besar biaya yang harus ditanggung oleh eksklusivitas, yang berujung pada konflik vertikal dan horizontal akhir-akhir ini; kebiasaan masyarakat menyebarluaskan dan menerima begitu saja berita bohong seakan-akan sebuah kenyataan dan kebenaran; sifat koruptif dan oportunistik para elite politik yang bertindak hampir-hampir tanpa etika dan nurani; dan ketidakhadiran negara dalam kehidupan sehari-hari masyarakat seperti melalui parkir liar dan premanisme. Padahal, semua persoalan itu salah satunya bersumber pada kebudayaan, mentalitas, dan karakter bangsa. Oleh karena itu, sekali lagi, jangan berharap penelitian yang menjadi bagian dari ilmu-ilmu humaniora akan menjadi prioritas selama tidak terjadi perubahan struktural secara paradigmatik dalam penyusunan dokumen rencana induk dan agenda penelitian nasional.

Begitu juga dengan jumlah sumber daya manusianya dan mutu perangkat pendukung lainnya tidak akan memadai karena semua rencana dan agenda berangkat dari premis yang ahistoris sehingga tidak akan memberi ruang kepada ilmu-ilmu humaniora memayungi pengembangan sumber daya manusia seperti yang diberikan kepada ilmu-ilmu alam dan ilmu-ilmu terapan. Negara lebih membutuhkan ahli bioteknologi, insinyur, dokter, atau teknisi daripada sejarawan, ahli bahasa, antropolog, atau ahli filsafat yang dianggap tidak akan mampu melakukan inovasi dan penemuan formula yang dapat dikomersialisasikan serta dimanfaatkan oleh sektor industri. Padahal, di negara maju yang dijadikan acuan, para ahli saat ini sudah jauh memfokuskan diri pada bidang-bidang seperti bioethics dan engineering ethics, yang semuanya bersumber pada ilmu-ilmu humaniora, bukan sekadar pada industri dan teknologi sebagai sebuah keterampilan teknis dan ketenagakerjaan.

Selama Indonesia terus menjadi konsumen dari konsep dan teori yang dikembangkan dari kenyataan historis dan budaya di luar dirinya yang diasumsikan berlaku universal serta tidak mampu membangun kerangka berpikir secara mandiri untuk melakukan penelitian dan "hilirisasinya", ketergantungan akan terus berlanjut dan sangat sulit membangun keunggulan bangsa. Melalui prinsip siap saji, penemuan baru yang didukung oleh ilmu pengetahuan dan teknologi untuk pengembangan industri yang menguntungkan secara ekonomis diyakini tetap saja bisa terjadi, tetapi dengan tingkat keberlanjutan yang rendah karena semua bukan merupakan satu kesatuan dari sistem budaya intelektual dan imajinasi yang bersumber dari revolusi cara berpikir bangsa.

Oleh sebab itu, penelitian yang menjadikan humaniora sebagai dasar berpikir yang 
memayungi penelitian tentang berbagai persoalan bangsa merupakan sesuatu yang sangat mendesak untuk dijadikan sebagai prioritas sehingga gerak kemajuan bangsa selalu dimulai dari cara berpikir yang bersumber dari masyarakat dan kebudayaanya, termasuk pengalaman yang pernah dilalui. Di dalam tradisi berpikir Barat, sebagai contoh, mitologi Yunani yang dipadu dengan mitologisasi atas Kristo-Yudaisme yang mengalami rasionalisasi merupakan sistem pengetahuan yang wajib diketahui untuk memahami diri sebagai satu kesatuan kebudayaan. Ironisnya, di Indonesia, hal itu dianggap sebagai sesuatu yang universal sehingga diadopsi sebagai miliknya dengan meninggalkan "mitologi Indonesia" di dalam ruang masa lalu yang dianggap tidak ada hubungannya dengan kebudayaan bangsa beserta kekinian dan masa depannya.

Mitos sebagai sebuah konsep langsung dihubungkan dengan sesuatu yang tidak rasional dan bukan bagian dari budaya intelektual serta imajinasi bangsa yang mampu ditransformasikan menjadi ilmu pengetahuan dan teknologi. Akibatnya, cara berpikir yang berusaha dibangun tidak bersumber pada kebudayaan dan pengalaman sendiri, tetapi kebudayaan dan sejarah bangsa lain. Buktinya, muatan yang terkandung dalam Pancasila, yang merupakan produk sejarah dari keberadaan bangsa dan negara Indonesia selama ini tidak pernah menjadi acuan dasar untuk membangun sistem ide untuk membangun kecerdasan dan produktivitas bangsa, kecuali hal-hal yang bersifat politis ideologis.

Maka, dalam konteks inilah perlu dilakukan pemahaman ulang atas struktur dan fungsi historiografi Indonesia sebagai satu kesatuan sistemik dengan kebudayaan bangsa, bukan sekadar konstruksi tentang masa lalu. Historiografi pada dasarnya adalah budaya intelektual dan imajinasi bangsa yang bersumber pada masa lalu, tetapi dibangun dalam struktur pemahaman dan penjelasan kekinian atas masa lalu dan berfungsi untuk menghadirkan cara berpikir visioner yang sangat diperlukan bagi masa depan. Sejarah merupakan peristiwa yang tertinggal di masa lalu dan dapat sampai ke masa kini melalui jejak yang ditinggalkannya. Sementara itu, historiografi selalu merupakan produk kekinian yang memahami dan menjelaskan masa lalu berdasarkan nilai-nilai yang berlaku ketika historiografi itu dikonstruksikan.

Melalui historiografi, masa lalu, masa kini, dan masa depan bertemu dalam satu ruang kebudayaan yang dinamis karena historiografi pada prinsipnya selalu aktual. Oleh karena itu, sebuah penelitian untuk menghadirkan "mitologi Indonesia" yang akan menjadi sumber cara berpikir bangsa perlu segera dilakukan. Jika cara berpikir di atas diterima, baru ada jaminan ilmu-ilmu humaniora umumnya dan sejarah khususnya dapat menjadi prioritas dalam penelitian di Indonesia.

\section{Historiografi dan "Hilirisasi"}

Tentu saja tidak semua persoalan yang muncul harus dibebankan pada cara berpikir para teknokrat dan dokumen rencana induk serta agenda penelitian yang telah disusun. Para ahli humaniora juga harus melakukan autokritik atas kesiapan perangkat keilmuan dan dirinya ketika dihadapkan dengan sesuatu yang relevan bagi kepentingan pembangunan bangsa. Dalam banyak kasus, ilmu-ilmu humaniora hadir hanya dengan retorika filosofis yang tidak realistis untuk dapat diterapkan dalam kehidupan sehari-hari. Ketika seorang sejarawan diminta untuk ikut serta merancang pembangunan nasional atau mencari 
jalan keluar permanen atas permasalahan yang dihadapi bangsa dan negara, sebagai contoh, sebagian besar tidak menguasai perangkat metodologis yang dapat digunakan untuk pekerjaan seperti itu karena historiografi yang dihasilkan bersifat antikuarian, yang hanya berguna untuk masa lalu. Oleh karena itu, beberapa prinsip dasar dalam sejarah sebagai ilmu perlu ditinjau ulang agar mampu membangun konstruksi baru kerangka berpikir agar dapat ikut serta dalam proses "hilirisasi” penelitian ketika tidak ada kesempatan dan otoritas untuk mengubah Rencana Induk Riset Nasional dan Agenda Riset Nasional yang sudah mendjadi dokumen administratif dan sekaligus politik itu.

Menurut Nussbaum (2016:xv), paling tidak ada tiga sumbangan penting humaniora, yaitu merangsang keingintahuan, tumbuhnya kemampuan berpikir kritis, dan membangun imajinasi. Ia lebih lanjut menyatakan bahwa tidak adanya tiga elemen itu dalam kehidupan setiap individu atau masyarakat akan berakibat pada "hilangnya keterampilan sangat bermanfaat yang mampu membantu mereka berhasil dalam bekerja dan kehidupannya" (Nussabaum, 2016:xvii). Ketika tiga hal tersebut dihubungkan dengan inovasi dan penemuan yang menjadi dua kata kunci berkaitan dengan pekembangan teknologi, yang diperlukan oleh industri agar mampu memberi keuntungan ekonomis dan bermanfaat bagi kepentingan masyarakat. Dapat dikatakan bahwa humaniora sudah memenuhi semua persyaratan "hilirisasi" sebagaimana dimaksud dalam dokumen yang secara resmi ditulis untuk keperluan itu.

Seperti telah disebutkan di atas, kemajuan teknologi dalam sejarah manusia tidak pernah lepas dari keingintahuan, pemikiran kritis, dan imajinasi. Hal itu misalnya dapat dilihat dalam sejarah ketika Louis Pasteur menemukan prinsip-prinsip vaksinasi, fermentasi mikrobial, dan teknik pasturisasi. Salah satu penemuannya yang berhasil menghentikan kontaminasi bakterial pada susu dan anggur, yang kemudian menjadi sesuatu yang fenomenal dalam teknologi pengawetan pangan, secara historis merupakan sebuah perwujudan dari kebudayaan. Pengalaman historis Christiaan Eijkman yang berhasil menemukan thiamine sebagai vitamin antineuritik, yang berguna untuk memerangi penyakit beri-beri yang melanda Indonesia pada masa kolonial, juga menunjukkan bagaimana kemampuan humaniora seseorang ketika berinteraksi dengan lingkungannya akan memacu timbulnya ide-ide baru yang menghasilkan ilmu pengetahuan dan teknologi baru. Selain itu, sebagian besar dari teknologi modern yang dikenal umat manusia saat ini bersumber dari imajinasi fiksi sains sebagai salah satu genre dalam sastra, yang kemudian dikonversi menjadi sesuatu yang nyata oleh para ilmuan.

Berdasarkan cara berpikir di atas, historiografi merupakan sesuatu yang sangat penting untuk membangun kebudayaan yang disebut Sartono Kartodirddjo sebagai "nilai-nilai yang berfungsi dalam menghayati kehidupannya sehari-hari dan dalam melaksanakan interaksi antara sesama” (Kartodirdjo, 2005:175). Dalam konteks ini, historiografi menjadi salah satu sumber yang mampu menghasilkan keterampilan imajinatif dalam proses "hilirisasi" penelitian. Hal itu berkaitan dengan asumsi dasar bahwa historiografi sebagai konstruksi atas masa lalu mengandung nilai-nilai bersifat sakral dan profan sekaligus. Sejarah pada dasarnya bukan hanya menyangkut identitas dan entitas bangsa yang berujung pada nasionalisme. Sejarah juga bukan hanya sebagai alat analitis yang dapat digunakan untuk merekonstruksi masa lalu untuk memahami dan menjelaskan masa kini serta berguna untuk merancang masa depan. Historiografi pada dasarnya juga sebuah naratif, kesadaran kolektif yang tertanam dalam kehidupan 
sehari-hari masyarakat pendukungnya.

Dalam konteks inilah, prinsip-prinsip yang disebut sebagai "mengonsumsi sejarah" dapat dijadikan dasar berpijak secara epistimologis untuk membangun inovasi dan bahkan penemuan, yang tidak hanya bermanfaat bagi masyarakat, tetapi juga dapat menjadi bagian dari industri. Merujuk pada keberadaan subjektivitas yang selalu ada pada setiap konstruksi sejarah sebagai produk historiografis, mitos merupakan sesuatu yang juga selalu dihasilkan oleh proses historiografi selain dari kenyataan-kenyataan dari masa lalu. Pada dasarnya, mitos tidak hanya mengandung unsur normatif, tetapi juga filosofis, yang melalui rasionalitas berpikir dan imajinasi dapat ditransformasikan menjadi ide-ide produktif. Oleh sebab itu, dalam konteks ini, mengonsumsi sejarah tidak selalu bermakna negatif.

Dalam sejarah Indonesia, industri gula, sebagai contoh, memiliki sejarah yang panjang sejak masa kolonial Belanda. Selama ini, pemahaman tentang sejarah industri gula hanya dikaitkan dengan eksploitasi kolonial yang berakibat pada pemiskinan terhadap rakyat Indonesia. Akan tetapi, tidak ada upaya untuk memahami sejarah industri gula dengan kehidupan sehari-hari sebagai "budaya gula", yang berhubungan dengan pola makan dan jenis kuliner yang ada di dalam masyarakat atau dalam kata lain industri gula sebagai kebudayaan. Persoalan utama yang muncul adalah apakah hubungan antara industri gula dan 'budaya gula" yang ada di dalam masyarakat dan adakah kaitannya dengan berbagai penyakit yang dialami masyarakat, khususnya diabetes militus dan obesitas?

Dalam konteks ini, "budaya gula" tidak hanya dilihat in situ dan berhenti di masa lalu, tetapi sebagai proses sejarah yang panjang sampai dengan kondisi kekinian yang berkaitan antara gula dan penyakit, yang terjadi pada masyarakat Indonesia secara keseluruhan. Pertanyaan itu penting karena selain industri gula tebu yang dikuasai oleh perusahaan besar, di Indonesia juga dikenal gula enau dan gula kelapa yang diproduksi oleh masyarakat. Jika gula tebu lebih berorientasi pada pasar ekspor pada masa kolonial, gula enau dan gula kelapa lebih berorientasi pada pasar lokal dan lebih banyak dikonsumsi oleh masyarakat. Dalam hal ini, apakah industri gula tebu berpengaruh terhadap tradisi kuliner masyarakat? Apakah modernitas dan kemerdekaan bangsa Indonesia berpengaruh terhadap pola konsumsi gula tebu masyarakat?

Cara berpikir yang sama dapat juga digunakan pada industri tembakau dan rokok. Seperti juga industri gula, hampir seluruh kajian sejarah tentang industri tembakau dan rokok mengacu pada persoalan ekonomis dan sosial, khususnya ketenagakerjaan. Akan tetapi, hampir-hampir tidak ada yang mencoba membayangkan konteks lain dari "budaya tembakau" yang berawal dari tradisi makan sirih sampai dengan berkembangnya tradisi merokok tembakau serta hubungnya dengan penyakit. Sebagai orang awam tentang farmakologi dan kedokteran, satu imajinasi yang muncul adalah apakah yang akan terjadi pada kesehatan para perokok jika rokok tembakau mereka dicampur dengan ekstrak sirih dan pinang?

Ketika sekelompok masyarakat tertentu terjebak pada tradisi buruk akibat pengaruh minuman terbuat dari fermentasi campuran air-gula dan ragi yang biasa digunakan untuk membuat roti-maka keberadaan konstruksi historis yang dibangun berdasarkan prinsip historiografi yang baru dibayangkan akan memunculkan ide-ide baru yang memberi kesempatan kepada masyarakat untuk tetap bisa menikmati kehangatan dan 
sensasi minuman tanpa harus memabukkan, sebagaimana orang dapat menikmati bir tanpa harus menjadi mabuk. Ketika teknologi dimaknai sebagai satu kesatuan sistem berpikir dan nilai maka imajinasi sejarah mampu membuka jalan bagi munculnya ide-ide baru tentang antidot, antidatum, atau antitoksin yang berhubungan dengan konsumsi masyarakat terhadap gula, tembakau, atau minuman fermentasi.

\section{Penutup}

Naratif sejarah bangsa sebagai produk dari keingintahuan, pikiran kritis, dan imajinasi itu akan mengalami proses komoditifikasi, yang dapat dengan mudah dikonversi menjadi ide-ide baru yang memiliki dasar kultural dan sekaligus historis. Dalam konteks ini, perkembangan sejarah publik atau sejarah populer akhir-akhir ini merupakan salah satu contoh yang menarik untuk diperhatikan lebih lanjut. Sejarah publik atau sejarah populer membuka peluang baru bagi sejarawan dalam menjalankan proses kerja kesejarahannya dan kesempatan praktis sebagai sebuah profesi yang penuh tantangan, tetapi bernilai ekonomis ketika dibingkai dalam kerangka berpikir "mengonsumsi sejarah". Komodifikasi tidak perlu dicurigai sebagai komersialisasi yang penuh dengan muatan kepentingan untuk mencari keuntungan ekonomis sebagai manifestasi keserakahan dan manipulasi, tetapi sebagai bagian dari inovasi yang sejalan dengan euforia yang dimaknai sebagai tantangan sekaligus peluang pada era (Revolusi) Industri 4.0 dan 5.0.

Komoditifikasi sejarah yang bergayut dengan kemajuan cepat teknologi dan sistem informasi yang didukung oleh perubahan paradigmatik mempermudah pekerjaan seorang sejarawan dan sekaligus menantang mereka untuk membangun metodologi baru yang mampu menghasilkan konstruksi sejarah, yang menghadirkan ide-ide baru sebagai bagian dari inovasi dan penemuan baru itu. Jika hal itu yang dilakukan, relevansi ilmu sejarah dalam kehidupan kekinian menjadi semakin nyata dan melampaui halhal di seputar nilai normatif yang selama ini selalu dianggap sebagai hal yang paling penting dari kajian sejarah. Melalui cara berpikir seperti ini, kajian sejarah tidak hanya mampu memahami kekinian untuk merancang masa depan secara normatif, tetapi juga memberi sumbangan nyata, baik kepada individu maupun masyarakat, tentang jenis-jenis tindakan dan peluang ekonomi apa yang dapat dilakukan.

Sejarah adalah inspirasi untuk para "pemimpi" melakukan tindakan-tindakan kreatif, inovatif, dan produktif pada era Industri 4.0 dan 5.0. Hasilnya, setiap anak bangsa mampu menciptakan peluang kewirausahaan, baik untuk dirinya sendiri maupun masyarakat yang luas, dalam rangka mewujudkan kesejahteraan dan kemakmuran bangsa, sebagaimana diamanatkan dalam sila "Keadilan Sosial Bagi Seluruh Rakyat Indonesia”. Sampai dengan tataran ini, sekali lagi dibuktikan bahwa Pancasila bukan sekadar ideologi politik, melainkan sebuah sistem ide dari kecerdasan intelektual dan kebudayaan sebuah bangsa yang bercita-cita membangun peradaban baru dunia melalui kemerdekaannya. Dalam konteks inilah, sejarah sebagai bagian dari ilmu-ilmu humaniora dapat menunjukkan baktinya sebagai sebuah ilmu.

\section{Daftar Pustaka}

Allen, R.C. (2006). The British Industrial Revolution in Global Perspective: How Commerce 
Created the Industrial Revolution and Modern Economic Growth. Oxford: Department of Economics and Nuffield College Oxford University.

Buchanan, A. (1975). “Technology and History”. Social Studies of Science, 5, hlm. 489-499.

Buhr, D. (2017). Social Innovation Policy for Industry 4.0. Germany: Frederich Ebert Stiftung.

Daulay, H. (2016). "Peraturan Menteri Riset, Teknologi, dan Pendidikan Tinggi Nomor 42 Tahun 2016 Tentang Pengukuran dan Penetapan Tingkat Kesiapterapan Teknologi (Technology Readiness Level). Hilirisasi Hasil Riset dan Pengembangan dalam Rangka Peningkatan Daya Saing”, 18 Oktober 2016.

de Groot, J. (2009). "Consuming History". Historians and Heritage in Contemporary Popular Culture. London: Routledge.

Direktorat Jendral Kelembagaan Iptek dan Dikti. (2016). "Kemenristekdikti Makin Giatkan Hilirisasi Riset ke Industri”, 22 Desember 2016, http://kelembagaan. ristekdikti.go.id/index.php/tag/hilirisasi-riset/.

Dewan Riset Nasional. (2016). “Agenda Riset Nasional 2016-2019”. Jakarta.

Epstein, S. (2008). "Culture of Science/Technology: Rethinking Knowledge, Power, Materiality, and Nature". The Annals of American Academy of Political and Social Science, Cultural Sociologyand Its Diversity, Vol. 619, September 2008, hlm. 165-182.

Heywood, P. dan Nida P.H. (2009). "Health Facilities at the District Level in Indonesia". Australia New Zealand Health Policy, No. 6, May 2009, hlm. 1-11.

"Hilirisasi Hasil Penelitian Harus Bermanfaat Bagi Masyarakat", Republika, 23 September 2015, http://www.republika.co.id/berita/pendidikan/dunia-kampus/15/09/23/ nv4wdj219-hilirisasi-penelitian-harus-bermanfaat-bagi-masyarakat.

"Hilirisasi Hasil Penelitian Harus Didukung", Tempo, 2 September 2016, https://nasional. tempo.co/read/800979/hilirisasi-hasil-penelitian-harus-didukung.

"Hilirisasi Riset untuk Kesejahteraan Masyarakat", USID, 2016, http://www.prestasiiief.org/index.php/id/feature/104-hilirisasi-riset-untuk-kesejahteraan-masyarakat.

Kartodirdjo, S. (2005). Sejak Indische Sampai Indonesia. Jakarta: Kompas.

Kementerian Riset, Teknologi, dan Pendidikan Tinggi. (2017-2015). "Rencana Induk Riset Nasional 2017-2015”, http://risbang.ristekdikti.go.id/reviewer/ RIRN12Desember.pdf.

Lembaga Ilmu Pengetahuan Indonesia. (2016). "Mendukung Hilirisasi Hasil Penelitian”, 30 Agustus 2016, http://lipi.go.id/lipimedia/mendukung-hilirisasihasil-penelitian/16137.

Mokyr, J. (1999). "The Industrial Revolutioan and the Netherlands: Why Did It Not Happened?. Amsterdam.

Morrar, R. dkk. (2017). "The Fourth Industrial Revolution (Industry 4.0): The Social Innovation Perspective". Technology Innovation Management Review, Vol. 7, issue 11, 2017, hlm. 12-20.

Nasution, M.K.M. (2016). "Hilirisasi Penelitian Berbasis Teknologi pada Perguruan Tinggi”, Analisa, 26 September 2016.

Neelakantan, V. (2014). "Health and Medicine in Soekarno Era Indonesia: Social Medicine, Public Health and Medical Education, 1949-1967". Phd. Thesis. University of Sydney.

Nussbaum, M.C. (2016). Not for Profit. Why Democracy Needs the Humanities. Princeton: Princeton University Press. 
"Undip Semarang Akan Contoh Hilirisasi Penelitian Tiongkok". Tribun Jateng, 6 Januari 2017, http://jateng.tribunnews.com/2017/01/06/undip-semarang-akan-contohhilirisasi-penelitian-tiongkok.

Purwanto, B. (2006). Gagalnya Historiografi Indonesiasentri. Yogyakarta: Ombak.

Santosa, B. (2017). "Budaya Inovatif, Inovasi Budaya”, Kompas, 13 November 2017. 